\title{
HOW IMPORTANT ARE CSR COMPANIES FOR NATIONS' GROWTH?
}

\author{
Marinko Škare' ${ }^{1}$, Tea Golja ${ }^{2}$ \\ Faculty of Economics and Tourism "Dr. Mijo Mirković”, Juraj Dobrila University \\ of Pula, Preradovićeva 1, 52100 Pula/Istria, Croatia \\ E-mails. ${ }^{1}$ mskare@unipu.hr (correspondingauthor); ${ }^{2}$ tgolja@unipu.hr
}

Received 30 April 2013; accepted 26 June 2013

\begin{abstract}
The paper provides new empirical evidence on the positive link between corporate social responsibility and income growth. Using available data for 26 countries over 2000-2008 we investigate cross-country growth differences by adding new variable (corporate social responsibility) to the standard growth regression model. We show that corporate social responsibility impact on growth is statistically significant but limited in size. Moreover, the inclusion of corporate social responsibility variable improves the fit of the regression. Countries with higher corporate social responsibility penetration as India achieve higher income growth rates. Evidence of the positive link between corporate social responsibility presented in this study encourage but further research on mechanism how socially responsible behavior affects growth is necessary.
\end{abstract}

Keywords: corporate social responsibility, cross country growth, dynamic panel, social impact hypothesis.

Reference to this paper should be made as follows: Škare, M.; Golja, T. 2013. How important are CSR companies for nations' growth?, Journal of Business Economics and Management 14(4): 776-790.

JEL Classification: O47, M14, O50.

\section{Introduction}

The literature examining the impact of corporate social behaviour on economic growth is relatively small. Somehow related studies on social capital issue can be found in the works of Putnam (1995), Helliwell and Putnam (1995), Hall and Jones (1996), Knack and Keefer (1997). Coleman (1988) looks for the differences in growth rates through trust, societal structure, social capital role in creation of human capital, economic payoffs to social capital and the role of civil society. More recent study of Espigares and López (2006) reveal a positive link between corporate social responsibility indicators and economic growth in OECD countries. They find positive and statistically significant (although not large) link between CSR and growth within the EU family members. Their research was limited to some variables associated to economic growth, not directly to growth itself. Related studies point to the possible positive nexus between firms' socially acceptable behaviour and growth progress. In line with the study of Espigares and 
López (2006) we find CSR firms to positively contribute to nations' economic growth. Previous studies on CSR - growth nexus were limited in data and lacking in clear growth model specification. Under well established Barro and Sala-i-Martin (2004) and Mankiw et al. (1992) we were able to find empirical evidence that CSR behaviour is important for nations' growth. Currently, CSR behaviour (measured through CSR firms performance indicators as proxy) on nations' economic growth is positive but limited. We find two clear reasons for such condition. First is that governments' are presently lacking in active CSR policies integrated in sustainable development policies. The second reason is that present CSR policy actions are badly structured - too regulatory and less market oriented. Countries with a clear CSR policy agenda strongly market oriented register bigger impact of CSR behaviour on growth (Germany, Norway, Sweden). Undoubtedly, CSR behaviour is to become a more important growth determinant in the future. Nations' with larger share of CSR companies will experience higher and more persistent growth rates by eliminating jobless growth and working poor limitations constraining future growth.

First section of the paper builds a conceptual framework for studying macroeconomic mechanisms and models if and how companies' socially responsible behaviour can affect economic growth. Section 2 provide related literature review regarding the social impact hypothesis. In section 3 a review on data and methodology we use in our analysis is presented. In section 4 we examine the effect of CSR companies on real output finding a positive relationship between CSR and country's real output and present model robustness test results to check if the results are robust to possible bias problem. We present our findings in the concluding section 5 .

\section{Corporate social responsibility and growth - is there a nexus?}

The so-called modern era of corporate social responsibility is very closely associated with the work of Bowen (1953). He pointed out that the corporate decision making process should not be focused solely on the economic issues but should also monitor social consequences of the usual business activities.

Additional attempts to define social responsibility of business occurred during the 1970s and the period of neo-classical economic doctrine. First, not to be forgotten is a very strong proponent of neo-classical economy and profit pursuit - Milton Friedman. He was arguing that business does not have responsibility, but people do have it. Managers could have responsibilities. For him a corporation is "an artificial person and in this sense may have artificial responsibilities, but "business" as a whole cannot be said to have responsibilities, even in this vague sense" Friedman (2007). Only the corporate executives are to be held responsible. Their responsibility is "to make as much money as possible while conforming to the basic rules of the society, both those embodied in law and those embodied in ethical custom". However, Friedman also stated that although a company does not have consciousness, the managers should be managing and leading the corporation in accordance to the laws and ethics. Making profits, according to Friedman, is the focal point of a company's existence, and furthermore, the company should 
obey the law and meet ethical requirements. These are to be considered three main responsibilities of the company. As such, Friedman was not far away from the notion of corporate social responsibility but was pointing on the responsibility of the company (which does not exists) versus the responsibility of the manager of the company.

In the 1970s, Davis (1973), pointed out that the CSR requires consideration of issues beyond the narrow economic, technical and legal requirements of the company. Later, during the 1970s, Carroll (1977) gave a profound definition of corporate social responsibility and his proposed CSR pyramid is likely one of the most well-known models of CSR today. Carroll recognises four levels of business responsibilities: economic, legal, ethical and philanthropic as he assumes "for CSR to be accepted by a conscientious business person, it should be framed in a way that the entire range of business responsibilities are embraced", Carroll (1991). His definition is categorised as the most durable due to its simplicity and easiness of understanding. Carroll's definition has been frequently reproduced in top management and CSR journals and various competing themes were assimilated in that model. Wahba (2007) in his study, which was the first of this kind in the Egyptian context, demonstrated that the market compensates the firms that care for the environment. In his research, environmental responsibility exerted a positive and significant coefficient on the firm market value measured by Tobin's q ratio. McGuire et al. (1988) concluded that with having good relationship with different stakeholders, firms might face less financial risk. Guenster et al. (2011) while analysing the stock prices between 1997 and 2004 found that socially responsible companies outperform non-CSR companies. Similar findings result from the research performed by Allouche and Laroche (2005), Orlitzky et al. (2003), Verschoor and Murphy (2002), Dowell et al. (2000), Konar and Cohen (2001).

Nevertheless, there are studies that have shown the neutral or negative relationship between financial and social performance. Line in line with the later studies goes the conclusion of the research performed by Galema et al. (2008). They could not find support for a positive association between financial performance and social strengths. They find a negative relationship between the two. This means that if management is to satisfy shareholders, stakeholders' interests have to be sacrificed. They research confirmed Ullmann (1985) view that stated that firm faces a trade-off between shareholder and stakeholder interest. Apart from them, the research performed by Wagner et al. (2002), also revealed a negative relationship.

Many of the studies such as those carried by Statman (2006), Guenster et al. (2011), McWilliams and Siegel (2001) found no statistically significant differences between socially responsible funds and stocks and the conventional ones.

Margolis (2003) completed a collection of 127 published empirical studies that examined the relationship between corporate social and corporate financial performance. The collection includes studies and findings from 1972 to 2000. Among them, there are findings, which fit in the above mentioned models; thus accepting or rejecting the social impact hypothesis. In 109 of 127 studies where corporate social performance has been treated as an independent variable, 54 pointed to a positive relationship between corpo- 
rate social and corporate financial performance, favouring the social impact hypothesis or fitting into the hybrid models assumptions. Seven studies found negative relationship, fitting into the Neoclassical model approach. A mixed relationship was found in 20 studies, thus fitting into the pure moral models approach. The majority of the studies that have treated the corporate social performance as a dependent variable have found a positive relationship, thus favouring the social impact hypothesis.

Chung-Hua Shen (2008) find that CSR companies outperform non-CSR companies in different markets and accounting measures. A related research by Lundgren (2011) show that companies are likely to engage in CSR actions if rewarded or pressured by stakeholders (government, financial sector, NGO, consumers and other agents on the market). Section II provide related literature review regarding the social impact hypothesis Shapiro and Cornell (1987), Preston and Douglas (1997). The literature examining the shift of focus hypothesis as suggested by Becchetti, Ciciretti and Hasan (2009) find no evidence on CSR effect on the firms' financial performance other then additional cost incurring to the firms. Contrary to majority of the studies supporting CSR activities and financial returns thesis, Cardebat and Sirven (2010) find a negative link between financial returns and CSR. The literature examining the effect of changes in firms' CSR activities on economy performance is relatively small and restricted to individual country study or OECD summary. An alternative view on growth theory is that CSR activities result in positive consumer response on the market and increased sales volume and prices improving economy performance. Particularly, as noticed by Heslin and Ochoa (2008) CSR companies open up new markets, alleviate poverty and improve countries in question performances. By doing so, companies build they world market share, receive above-world-market price paid for their product creating new customers and markets for their products. This is a win-win situation for all parties on the market and economies as well.

We focus on measuring the impact of firms' socially responsible behaviour on economic growth dealing with social impact hypothesis. This paper studies the importance of socially responsible firms for national economies by investigating the nexus between CSR firms and country's registered economic growth. Extensive research on economic growth determinants can be found in Barro, Sala-i-Martin (1991, 2004), Mankiw et al. (1992), Aghion (2009), De La Croix and Michel (2008), Acemoglu (2009). Their results identifies about 21 variable and their possible connection with economic growth ranging from starting level of GDP per capita to degree of capitalism. None of these researches investigates possible nexus between corporate social responsibility and economic growth.

\section{Data, methodology and pre-estimation specification}

The methodological approach was based on the collective measurement of the CSR components - elements - using indexes as used by Waddock and Graves (1997). Amongst the available and world known CSR indexes (such as FTSE KLD 400 Social Index, Dow Jones Sustainability Indexes, Ethibel Sustainability Index) the Dow Jones Sus- 
tainability World Index was chosen. Dow Jones Sustainability World Index 2009/2010 represents the top $10 \%$ of the leading sustainability companies out of the biggest 2500 companies in the Dow Jones Global Total Stock Market Index.

A defined set of criteria is used to assess the opportunities and risks deriving from economic, environmental and social developments for the eligible companies. A major source of information is the SAM questionnaire that is completed by companies participating in the annual review. Further sources include company and third-party documents as well as personal contacts between the analysts and companies. Dow Jones Sustainability World index 2009/2010, as on 30th of September 2009, consisted of 317 corporations, from 26 countries $^{1}$ and different industrial sectors. The complete analysis and econometric modelling was based on the data retrieved from the corporations' annual reports that was further extended with appropriate macroeconomic variables entering the Cobb-Douglas function. The annual reports were filtered using Capital IQ and Bloomberg.

This panel consists of annual observation for 25 countries over the period 2000-2008. Ultimately, the analysis was made on 309 corporations from 25 different countries in the period from 2000-2008 (9 years). The beginning of the sample is constrained by the data availability on the CSR companies and the end of the data by the availability of the financial indicators (particularly Altman Z score). Within the panel, 8 corporations' reports from the DJSWI could not be tracked /or were missing. Still, we deal with a strongly balanced panel in our analysis (see Table 2).

Econometric Methods and Pre-estimation Specification

To investigate the effect of CSR companies on the level of national output we set up a generalised Barro and Sala-i-Martin (2004), Mankiw et al. (1992) growth equation of the form

$$
\gamma=\alpha+\beta_{1} x_{1}+\beta_{2} x_{2}+\ldots+\beta_{n} x_{n}+u_{i t},
$$

with $\gamma=$ real GDP per capita and $x_{1}, \ldots x_{n}$ vectors of explanatory variables.

Equation (1) can be expressed in a form

$$
\gamma=\alpha+\beta_{1} K+\beta_{2} L+\ldots+\beta_{3} H+\beta_{4} C S R+u_{i t},
$$

with $\alpha$ - level of technology, $K$ - total gross fixed capital formation in \% of GDP as proxy for capital stock, $L$ - labour force, $H$ - education index as proxy for human capital stock and CSR - explanatory variables for CSR companies. Taking logarithms we get a linearized Cobb-Douglas production function relationship investigating the impact of CSR companies on growth

$$
\ln Y=\alpha+\beta_{1} \ln K+\beta_{2} \ln L+\ldots+\beta_{3} \ln H+\beta_{4} \ln C R S+u_{i t} .
$$

\footnotetext{
${ }^{1}$ Countries in the panel: United Kingdom, Italy, Germany, Japan, Australia, France, Spain, Canada, Finland, Netherlands, Norway, Sweden, South Africa, Switzerland, China, Ireland, Denmark, Portugal, South Korea, Hong Kong, Thailand, Brazil, Belgium, India, USA.
} 
Explanatory variables used to capture the impact of CSR companies on growth lists in Table A1.

Following Badi (2008) we fit equation of the form

$$
y_{i t}=\alpha+X_{i t}^{\prime} \beta+u_{i t},
$$

$i=1, \ldots, N ; t=1, \ldots, T$ with $i$ denoting countries (cross section dimension), $t$ denoting time (time series dimension) and $X_{i t}$ containing set of the variables from table A1. Real output $\left(y_{i t}\right)$ is a function of $(\alpha)$ level of technology), $X_{i t}$ (explanatory variables) and all others factors that affect national output $\left(u_{i t}\right)$ including unobservable country specific effect ( $\mu_{I}$ - unmeasured business cycles effects), time-varying characteristics $(\lambda-$ technological progress) and remainder stochastic disturbance term $\left(v_{i t}\right)$. Theoretical and real life assumptions of business cycles and technology progress suggest the two-way error component regression model as appropriate to fit the data. In the two-way error component regression model unobservable countries' individual specific effects (business cycles) and unobservable time specific (technological progress) effects $\lambda_{t}$ ) are included in the components disturbances Badi (2008)

$$
u_{i t}=\mu_{i}+\lambda_{t}+v_{i t}
$$

To account for cross-sectional and temporal dependence in the panel (heteroskedascity and serial correlation after modified Wald test and Wooldridge test for serial correlation) we transform (3) and then estimate using two-way fixed effect Driscoll and Kraay (1998) robust standard errors as in Hoechle (2007)

$$
\tilde{y}_{i t}=\tilde{x}_{i t}^{\prime} \theta+\tilde{\varepsilon}_{i t}
$$

and dynamic model as proposed by Arellano and Bond (1991)

$$
\ln =\left(\frac{Y}{L_{i t}} \beta_{1} \frac{Y}{L_{i, t-1}}+\beta^{\prime}(L) x_{i t}+\lambda_{t}+\eta_{i}+v_{i t}\right),
$$

with $Y / L=$ GDP per unit of labor force, Depr $=(n+g+\delta)$ as defined in Mankiw et al. (1992) with unobservable country specific effect (business cycle) and time effect (technology progress).

\section{Empirical results}

Table 1 provide the results of a Two-way fixed Driscoll-Kraay estimation since test for inclusion of business cycle country-specific effect and technology progress-time effect show the presence of individual and time effect (statistically significant). Estimated coefficients are significant suggesting CSR companies can contribute to nations' economic growth. Positive (and statistically significant) link to growth is found for gross profit, working capital, number of total employees, accounts receivable, current, quick ratio 
and Altman Z score. Technology progress (time dummies effect) and individual business cycle specific fixed effect are significant and therefore included in the model. Not all CSR variables have positive signs. We find that CSR companies mainly positively affect country's growth except for the models (3), (5), (8), (13) with statistically significant negative impact on growth.

Negative affect of CSR variables such as changes in total assets, total debt, price earning ratio, inventory turnover, net change in cash can be explained by possible profitabilityliquidity-solvency-stability disequilibrium during the observed period. Not only, since lagged GDP variables significantly affect future GDP trend which are not accounted in this model this could be a possible bias constraint (if compared to the dynamic models results). Adjusted coefficient of determination is sufficiently large with statistically significant estimates in models (1)-(17).

Multi-factor productivity depending on the current level of technology has a largest and statistically significant share in all estimation models. The regression results in table 1, confirm that activities and performance of CSR companies has a positive impact on the level of output per labor force unit. This is particularly true for the Altman Z score variable as proxy for the CSR companies overall performance during the observed period. Signs and values for other non-CSR variables and associated coefficient estimates are in accordance to the theory and within expected limits.

We try to obtain more efficient estimates using two-step GMM (Arellano-Bond estimator with robust standard errors) with and without time effects dummies (18). Since other growth studies show GDP depending in large part on it's values in previous periods, we include lags of GDP per unit of labor force as regressor. In relation to the Table 1 , we can see that technology share in growth is significantly smaller and statistically not significant for models (1)-(4) and (10)-(14). This point to a possible bias between multi-factor productivity (level of technology) and technological progress included in the time effect. Whenever time effect is statistically significant the level of technology is not and vice versa. Coefficient estimates for most CSR variables show positive affect of CSR companies on growth except for price earning ratio, inventory turnover and accounts receivable turnover. The largest and statistically most significant impact is registered for the Altman $\mathrm{Z}$ score variable.

Other regressors in the model have expected signs and values within expected boundaries. Specification tests, Arellano-Bond test for autocorrelation and Sargan test for overidentifying restrictions confirms the null of serially uncorrelated errors and instruments validity. Because of possible bias between level of technology and time effect we estimate dynamic growth equation without time effect.

Table 3 summarizes the results of estimating equation (18) showing the impact of CSR companies on growth. First we observe that level of technology is statistically significant for all models, particularly to one with time effect included. Coefficient estimate for level of technology retains the largest share in growth followed by lagged Y/L values.

Negative link between CRS and growth is found for net change in cash (not statistically significant), total asset turnover, inventory turnover (not statistically significant) 


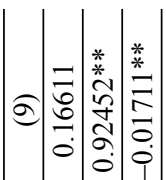

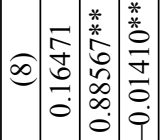

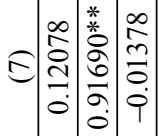

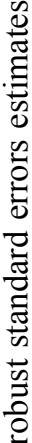

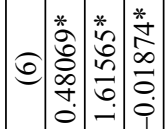

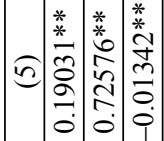

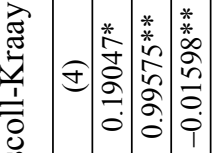

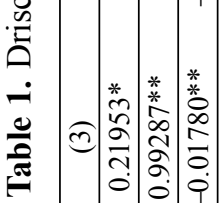

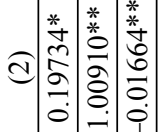

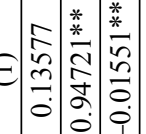

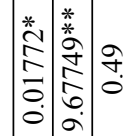

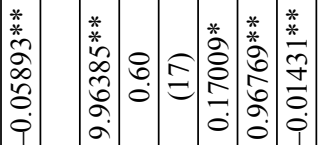

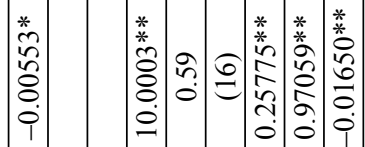

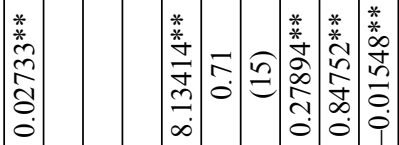

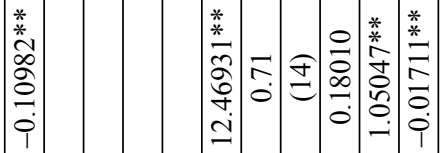

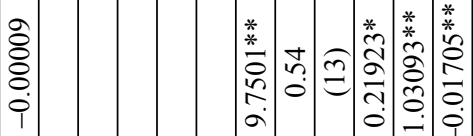

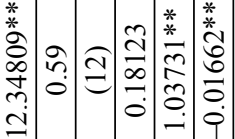

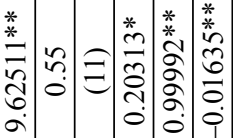

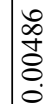

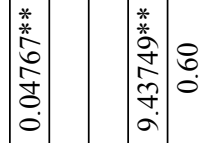

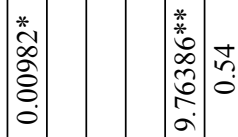

苂

$\underset{*}{*} \underset{*}{*} \sim$

ลิ

a.

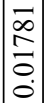

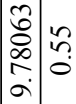

要

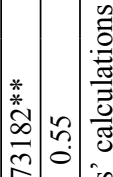

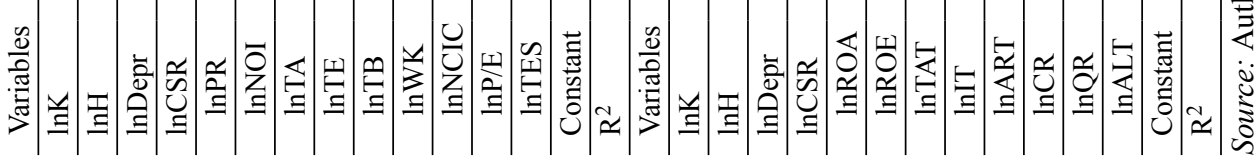




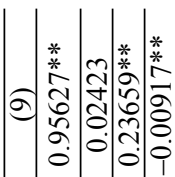

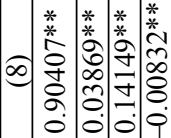

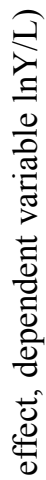

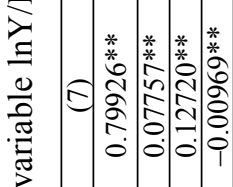

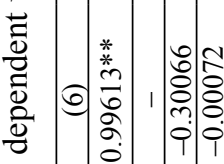

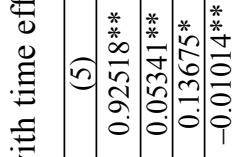

营

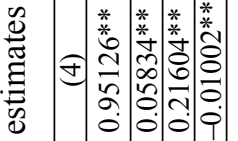

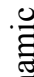

䓀

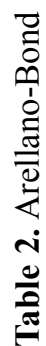

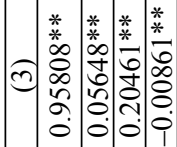

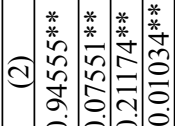

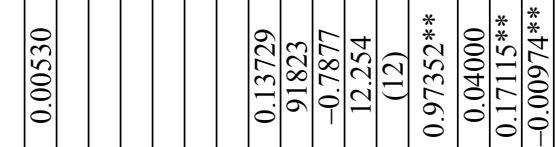

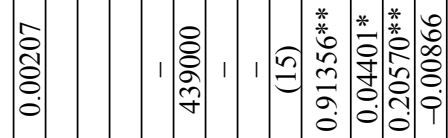

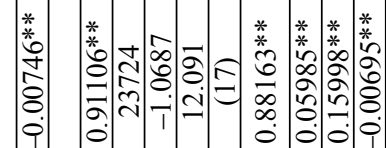

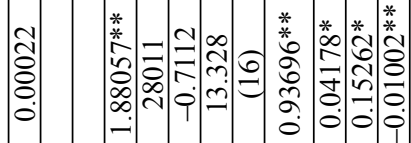

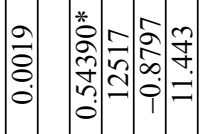

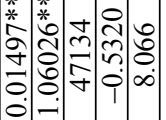

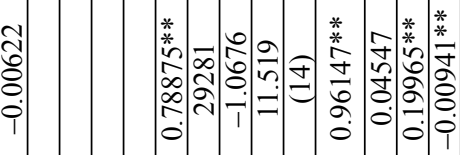

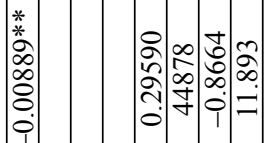

章

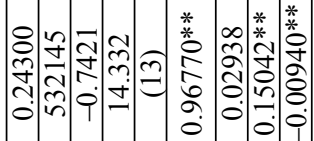

$\mid \begin{aligned} & \vec{b} \\ & \vdots \\ & \vdots \\ & 0\end{aligned}$

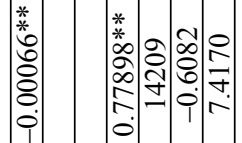

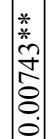

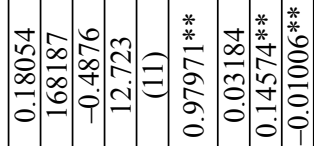

$*$
$*$
$*$
0
0
$\vdots$
$\vdots$
0

సิ่

ำ

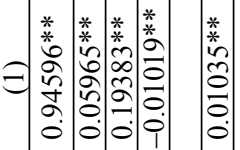

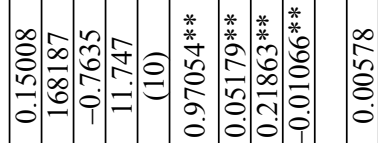

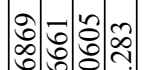

:

응

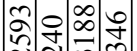

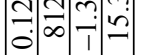

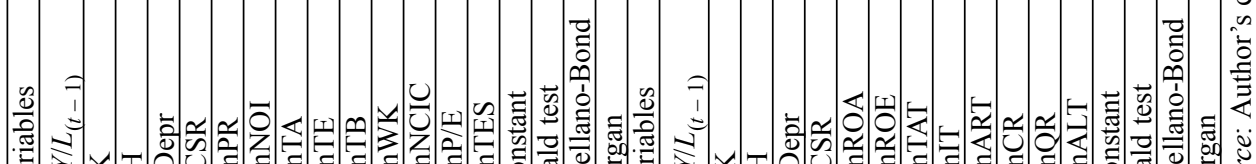
尝 


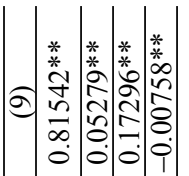

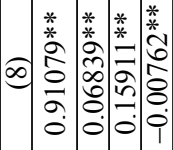

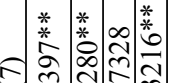

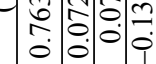

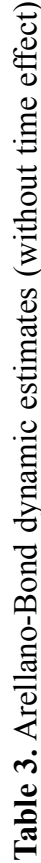

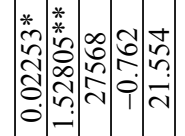

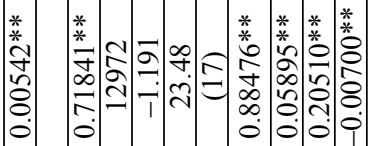

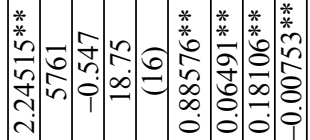

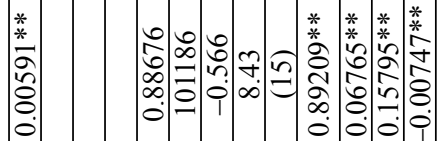

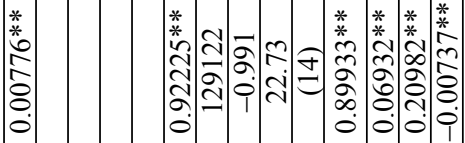

:

:

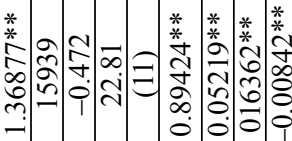

童

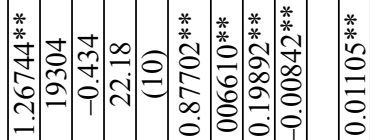

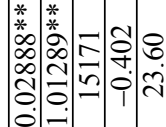

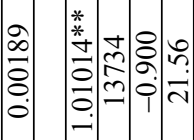

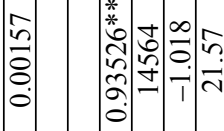

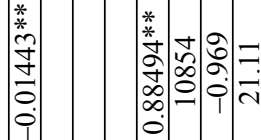

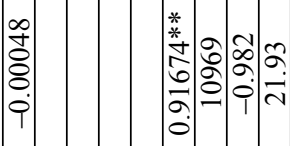

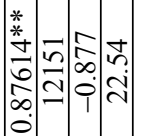

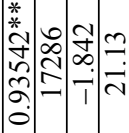

:

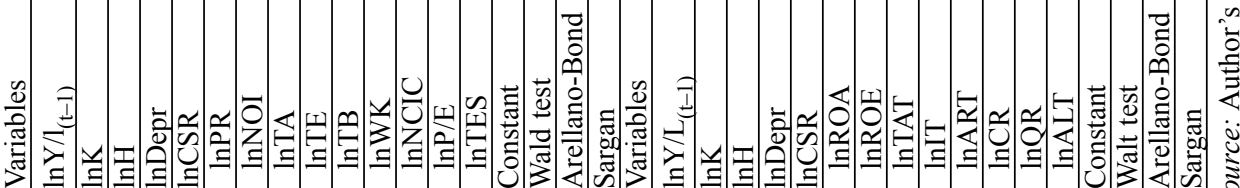

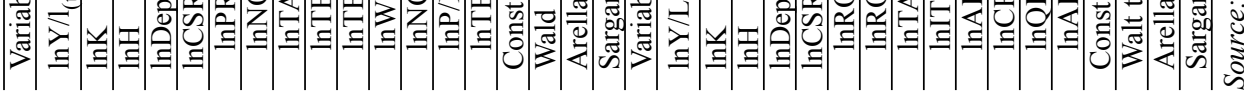


and accounts receivable turnover. Model specification test, Arellano-Bond, Sargan support the model validity rejecting the presence of serial correlation and overidentifying restrictions.

Results listed in tables 1, 2 and 3 show that business performance of CSR firms has (generally) positive impact on nations' growth. A CSR firm enjoys better image perception by consumers on the market resulting in higher demand for their product. Our results confirm the results of Espigares and López (2006) that CSR companies are more concentrated in developed economies. CSR firms positively and strongly affect the longrun growth through increased competitiveness, better risk management, more flexible labor markets, rising human capital stock, product diversification, cost savings, access to new markets, better customer expectation insight.

When we include CSR variables in the standard growth regression models the impact of capital (share in GDP growth) on long run output is lower then in Barro $(1991,2004)$ or Mankiw et al. (1992). Aggregate share of CSR companies in long run growth currently is below that of capital, human capital or technology. When we look at the panel growth regression separately for each year (2000-2008) we observe a strong rise of the CSR share in output at the expenses of other growth determinants (capital, human capital and technology).

Our analysis show that further research investigating CSR and growth link should focus on the Altman $\mathrm{Z}$ score as best proxy in measuring CSR impact on growth. Comparing our results with those of Espigares and López (2006) we find CSR business performance indicators to be more robust over relative indicators such as number of CSR companies in a country, CSR companies per person or number of CSR companies included in the FTSE4Good. Relative indicators are more vulnerable to bias and endogeneity issues than business performance indicators directly related to CSR firms. Our estimates of CSR firms impact on growth is within expected level. Study of Espigares and López (2006) find positive correlation (0.242) between GDP per capita and the number of CSR firms in a country. The adjusted $\mathrm{R}^{2}$ is fairly strong showing that our modified Solow model can explain between $49 \%$ and $71 \%$ of income cross country variations (for the countries included in the panel).

\section{Conclusions}

The analysis in this paper show that CSR firms business performance has positive effect on income growth (GDP). Positive impact of CSR firms on growth remains statistically significant even after controlling for different CSR proxy indicators (17 business performance measures) and between countries effect or time effect as proxy for technological advancement. The results support the research of Espigares and López (2006) using relative CSR indicators as proxy to explore the link between CSR and income growth in OECD countries. Our study confirms their findings using most resent available data on CSR and using different cross country growth regression. Regression results prove robust to different CSR proxy indicator inclusion retaining stable fit of the regression (adjusted $\mathrm{R}^{2}=0.58$ ). Altman $\mathrm{Z}$ score indicator for CSR firms improves substantially 
the fit of the regression link between CSR and income growth in selected countries.

The fact that countries with more companies moving from profit oriented to strategic philanthropy (CSR penetration) resulting in access to new markets, new demand, consumer premiums, product and service innovation, generating increasing revenue tend to grow stronger should motivate policy makers. Consumers prefer service and products from socially responsible companies ensuring a new growth platform for CSR firms and actual product differentiation from the competition. Policy makers must find a way to support the transition from profit to CSR oriented business. This means they must move from crude regulatory and discretionary policy to more flexible CSR promoting policies. Given our results showing developed economies register higher demand for socially responsible behavior and Benabou and Tirole (2010) research on the key role of image concern in promoting socially responsible behavior, it could seem surprising that CSR share in growth is not larger. One possible explanation is that lack in the policy coordination, multi-stakeholder forums, CSR transparency and promotion, failure to divert public opinion toward CSR engaging firms, detached sustainable development policy but foremost failure to recognize the role of image concern account for most of constraints individual and corporate social responsibility development process face. We show CSR to be a new promising growth and development factor that limits market failures negative impact on growth. Not only, fostering demand for CSR products create new markets and demand relieving jobless growth and working poor constraints. This is important since the Asian miracle economies will face this issue very soon having significant consequence on the world economy.

In this study we have suggested that cross country variations in income growth can be better understood if CSR variables are included in the extended Solow model or other forms of growth regressions. Our research has several important implications. First, future stages of economic development demand extension of traditional growth models and inclusion of corporate social responsibility behavior variables. Second, only limited research on the nexus between CSR and growth exists and further investigation on the subject is needed. Third, relative indicators as proxy for CSR suffer from significant bias and endogeneity issues in cross country analysis.

Our investigation we hope will encourage more empirically oriented future research on the subject and it is our humble contribution to the growth theory field.

\section{References}

Acemoglu, D. 2009. Introduction to modern economic growth. USA: Princeton University Press. Aghion, P. H. P. 2009. The economics of growth. USA: MIT Press.

Allouche, J.; Laroche, P. 2005. A meta-analytical investigation of the relationship between corporate social and financial performance, Revue de gestion des ressources humaines 57(1): 8-41.

Arellano, M.; Bond, S. 1991. Some tests of specification for panel data: Monte Carlo evidence and an application to employment equations, The Review of Economic Studies 58(2): 277.

http://dx.doi.org/10.2307/2297968

Badi, B. 2008. Econometric analysis of panel data. Second edition. New York: John Wiley \& Sons, Inc. 
Barro, R. J. 1991. Economic growth in a cross section of countries, Quarterly Journal of Economics 106(2): 407-443. http://dx.doi.org/10.2307/2937943

Barro, R. J.; Sala-i-Martin, X. 2004. Economic growth. USA: MIT Press.

Benabou, R.; Tirole, J. 2010. Individual and corporate social responsibility, Economica: London School of Economics and Political Science 77(305): 1-19, 01.

Becchetti, L.; Ciciretti, R.; Hasan, I. 2009. Corporate social responsibility and shareholder's value: an event study analysis, Bank of Finland Research Discussion Paper No. 1/2009.

Bowen, H. R. 1953. Social responsibilities of the businessman. New York: Harper \& Row.

Cardebat, J. M.; Sirven, N. 2010. What corporate social responsibility reporting adds to financial return?, Journal of Economics and International Finance 2(2): 020-027.

Carroll, A. B. 1977. Managing corporate social responsibility. Boston: Little, Brown.

Carroll, A. B. 1991. The pyramid of corporate social responsibility: toward the moral management of organizational stakeholders, Business Horizons 34(4): 39-48.

http://dx.doi.org/10.1016/0007-6813(91)90005-G

Chung-Hua Shen, Y. C. 2008. Ambition versus conscience, does corporate social responsibility pay off? The application of matching methods, Journal of Business Ethics 88(1): 133-153.

Coleman, J. S. 1988. Social capital in the creation of human capital, The American Journal of Sociology 94: S95-S120. http://dx.doi.org/10.1086/228943

De La Croix, D.; Michel, P. M. 2008. A theory of economic growth. Cambridge: Cambridge University Press.

Davis, K. 1973. The case for and against business assumption of social responsibilities, Academy of Management Journal 16: 312-322. http://dx.doi.org/10.2307/255331

Dowell, G.; Hart, S.; Yeung, B. 2000. Do corporate global environmental standards create or destroy market value?, Management Science 46(8): 1059-1074.

http://dx.doi.org/10.1287/mnsc.46.8.1059.12030

Driscoll, J. C.; Kraay, A. C. 1998. Consistent covariance matrix estimation with spatially dependent panel data, The Review of Economics and Statistics 80(4): 549-560.

http://dx.doi.org/10.1162/003465398557825

Espigares, J. L. N.; López, J. M. G. 2006. Responsabilidad social corporativa y crecimiento económico [Corporate social responsibility and economic growth], Estudios de Economía Aplicada 24: 637-665.

Friedman, M. 2007. The social responsibility of business is to increase its profits, in W. C. Zimmerli, K. Richter, M. Holzinger (Eds.). Corporate ethics and corporate governance part IV. Berlin-Heidelberg: Springer, 173-178. http://dx.doi.org/10.1007/978-3-540-70818-6_14

Galema, R.; Plantinga, A.; Scholtens, B. 2008. The stocks at stake: return and risk in socially responsible investment, Journal of Banking \& Finance 32(12): 2646-2654.

http://dx.doi.org/10.1016/j.jbankfin.2008.06.002

Guenster, N., et al. 2011. The economic value of corporate eco-efficiency, European Financial Management 17(4): 679-704. http://dx.doi.org/10.1111/j.1468-036X.2009.00532.x

Hall, R. E.; Jones, C. I. 1996. The productivity of nations, NBER Working Papers No. 5812.

Helliwell, J. F.; Putnam, R. D. 1995. Economic growth and social capital in Italy, Eastern Economic Journal 21(3): 295-307.

Heslin, P. A.; Ochoa, J. D. 2008. Understanding and developing strategic corporate social responsibility, Organizational Dynamics 37(2): 125-144. http://dx.doi.org/10.1016/j.orgdyn.2008.02.002 Hoechle, D. 2007. Robust standard errors for panel regressions with cross-sectional dependence, Stata Journal 7(3): 281. 
Knack, S.; Keefer, P. 1997. Does social capital have an economic payoff? A cross-country investigation, The Quarterly Journal of Economics 112(4): 1251-1288.

http://dx.doi.org/10.1162/003355300555475

Konar, S.; Cohen, M. A. 2001. Does the market value environmental performance?, The Review of Economics and Statistics 83(2): 281-289. http://dx.doi.org/10.1162/00346530151143815

Lundgren, T. 2011. A microeconomic model of corporate social responsibility, Metroeconomica 62(1): 69-95. http://dx.doi.org/10.1111/j.1467-999X.2010.04087.x

Mankiw, N. G.; Romer, D.; Weil, D. N. 1992. A contribution to the empirics of economic growth, The Quarterly Journal of Economics 107(2): 407. http://dx.doi.org/10.2307/2118477

Margolis Joshua, W. J. 2003. Misery loves company: rethinking social initiatives by business, Administrative Science Quarterly 48(2): 268-305. http://dx.doi.org/10.2307/3556659

McGuire, J. B.; Sundgren, A.; Schneeweis, T. 1988. Corporate socially responsibility and firm financial performance, Academy of Management Journal 31(4): 854-872.

http://dx.doi.org/10.2307/256342

McWilliams, A.; Siegel, D. 2001. Corporate social responsibility: a theory of the firm perspective, Academy of Management Review 26(5): 117-127.

Orlitzky, M.; Schmidt, F. L.; Rynes, S. L. 2003. Corporate social and financial performance: a metaanalysis, Organization Studies 24(3): 403-441. http://dx.doi.org/10.1177/0170840603024003910

Preston, L. E.; Douglas, P. O. 1997. The corporate social-financial performance relationship: a typology and analysis, Business and Society 36(4): 419-429.

http://dx.doi.org/10.1177/000765039703600406

Putnam, R. 1995. Bowling alone: America's declining social capital, Journal of Democracy 6: 65-78. http://dx.doi.org/10.1353/jod.1995.0002

Shapiro, C. A.; Cornell, B. 1987. Corporate stakeholders and corporate finance, Financial Management 16(1): 5-14. http://dx.doi.org/10.2307/3665543

Statman, M. 2006. Socially responsible indexes, The Journal of Portfolio Management 32(3): 100-109. http://dx.doi.org/10.3905/jpm.2006.628411

Ullmann, A. A. 1985. Data in search of a theory: a critical examination of the relationships among social performance, social disclosure, and economic performance of US firms, Academy of Management Review 10(3): 540-557.

Verschoor, C. C.; Murphy, E. A. 2002. The financial performance of large US firms and those with global prominence: how do the best corporate citizens rate?, Business and Society Review 107(3): 371-380. http://dx.doi.org/10.1111/1467-8594.00141

Waddock, S. A.; Graves, S. B. 1997. The corporate social performance-financial performance link, Strategic Management Journal 18(4): 303-319.

http://dx.doi.org/10.1002/(SICI)1097-0266(199704)18:4<303::AID-SMJ869>3.0.CO;2-G

Wagner, M., et al. 2002. The relationship between the environmental and economic performance of firms: an empirical analysis of the European paper industry, Corporate Social Responsibility and Environmental Management 9(3): 133-146. http://dx.doi.org/10.1002/csr.22

Wahba, H. 2007. Does the market value corporate environmental responsibility? An empirical examination, Corporate Social Responsibility and Environmental Management 15(2): 89-99. http://dx.doi.org/10.1002/csr.153 


\section{APPENDIX}

Table A1. Variable names and definition

\begin{tabular}{lc}
\hline Variable name & Definition \\
\hline $\mathrm{Y}$ & Real GDP per capita \\
\hline $\mathrm{K}$ & Total gross fixed capital formation in \% of GDP \\
\hline $\mathrm{L}$ & Labour force (in 000) \\
\hline $\mathrm{H}$ & Education index \\
\hline CSR & Explanatory variables for CSR companies \\
\hline PR & Gross profit \\
\hline NOI & Net operating income \\
\hline TA & Total assets \\
\hline TE & Total equity \\
\hline TB & Total debt \\
\hline WC & Working capital \\
\hline NCIC & Net change in cash \\
\hline P/E & P/E ratio \\
\hline TE & Total employees number \\
\hline ROA & Return on assets \\
\hline ROE & Return on equity \\
\hline TAT & Total asset turnover \\
\hline IT & Inventory turnover \\
\hline ART & Accounts receivable turnover \\
\hline CR & Current ratio \\
\hline QR & Quick ratio \\
\hline ALT & Altman $Z$ score \\
\hline
\end{tabular}

Source: FTSE KLD 400 Social Index, Dow Jones Sustainability Indexes, Ethibel Sustainability Index, Dow Jones Sustainability World index 2009/2010, as on 30th of September 2009, consisted of 317 corporations, from 26 countries and different industrial sectors. Data retrieved from the corporations' annual reports and filtered by using Capital IQ and Bloomberg. We use aggregated data on country level for all CSR listed companies in Dow Jones Sustainability World Index.

Marinko ŠKARE. PhD, Full Professor. Professor of Economics, Economic Research Journal Editor in Chief, Member of Editorial Board of several international journals, Faculty of Economics and Tourism "Dr. Mijo Mirković" in Pula, Juraj Dobrila University of Pula. He served as Assistant Dean for Education, Faculty of Economics \&Tourism, Pula, Assistant Dean for International Cooperation, Faculty of Economics \& Tourism, Pula, Main and Team Researcher on several scientific projects, Former Dean of the Faculty of Economics \& Tourism, Pula and Former Vice President for International Cooperation, Juraj Dobrila University of Pula. He has published several books and a large number of scientific papers on the subject of economic growth, welfare economics and poverty, human capital, economics in transition, economic philosophy and monetary economics. He is member of the American Economic Association, Royal Economic Society, Economic History Association, Economic History Society, and Association for Comparative Economic Studies.

Tea GOLJA. PhD, Senior Researcher at the Faculty of Economics and Tourism "Dr. Mijo Mirković", Member of Editorial Board of several international journals, Main and Team Researcher on several projects, Lead Auditor on ISO 9001:2008 Standard. She has published many scientific papers on the subject of corporate social responsibility, corporate governance, inclusive business and sustainable development. She is a member of Global Development Network. 